\title{
Gigantic retroperitoneal metastatic seminoma encasing the aorta in a young man
}

\author{
Abdul Wahab, ${ }^{1}$ Muhammad Hashim Hayat, ${ }^{2}$ Amman Yousaf ${ }^{0},{ }^{3}$ Raseen Tariq ${ }^{4}$
}

${ }^{1}$ Internal Medicine, University of lowa Healthcare, lowa City, Iowa, USA

'Division of Gastroenterology, Hepatology and Nutrition, Department of Medicine, Vanderbilt University Medical Center, Nashville, Tennessee, USA

${ }^{3}$ Internal Medicine, McLaren Health Care Corporation, Flint, Michigan, USA

${ }^{4}$ Gastroenterology and Hepatology, Mayo Clinic, Rochester, Minnesota, USA

\section{Correspondence to} Dr Amman Yousaf; ayousafmd2@gmail.com

Accepted 17 August 2021

Check for updates

(c) BMJ Publishing Group Limited 2021. No commercial re-use. See rights and permissions. Published by BMJ.

To cite: Wahab A, Hayat MH,
Yousaf A, et al. BMJ Case
Rep 2021;14:e243190.
doi:10.1136/bcr-2021-
243190

\section{DESCRIPTION}

A 30-year-old man with no significant medical history presented with worsening of lower abdominal discomfort and a weight loss of 70 pounds during the past 6 months. Physical examination was significant for a large, firm, non-tender, irregular mass in the lower abdomen, more prominent on the left of the midline, and a small-sized non-tender swelling of the right testicle. Lactate dehydrogenase was $1562 \mathrm{U} / \mathrm{L}(135-225 \mathrm{U} / \mathrm{L})$, uric acid $8.2 \mathrm{mg} / \mathrm{dL}$ (3.4-7.0 mg/dL), serum $ß$-human chorionic gonadotropin (HCG) $85 \mathrm{mIU} / \mathrm{mL}$ and alpha-fetoprotein (AFP) $1.3 \mathrm{ng} / \mathrm{mL}(0.0-9.0 \mathrm{ng} / \mathrm{mL})$. CT scan of the abdomen and pelvis showed a large retroperitoneal mass encasing the abdominal aorta and its branching (figure $1 \mathrm{~A}$ ) and compressing the inferior vena cava (figures 1B,C and 2). Testicular ultrasound (US) showed a small right testicular mass with internal vascularity (figure $3 \mathrm{~A}, \mathrm{~B}$ ).

The patient underwent right-sided orchiectomy and US-guided biopsy of the retroperitoneal mass. Histopathology and immunopathology confirmed metastatic seminoma (figure 4A,B). After semen cryopreservation, the patient was started on chemotherapy. The patient has received four cycles of bleomycin, etoposide and cisplatin-based chemotherapy and no complications have been report till date (on 3-month follow-up).

Testicular germ cell tumours are the most common cancers in men aged 15-39 years with an increasing incidence rate during the last four decades. ${ }^{1}$ Seminoma is the most common subtype of testicular malignancy and it originates from seminiferous

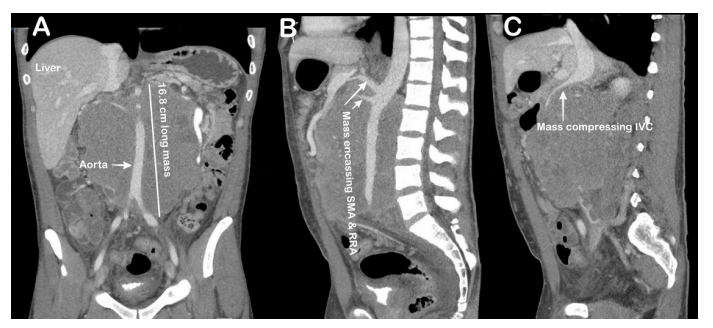

Figure 1 Contrast-enhanced $\mathrm{CT}$ scan of the abdomen and pelvis. (A) Coronal view and $(B, C)$ sagittal views showing a large retroperitoneal mass measuring $16.8 \times 9.8 \times 15.4 \mathrm{~cm}$ in $\mathrm{CC} \times \mathrm{AP} \times \mathrm{TR}$ dimensions, encasing aorta (white arrow in A) and extending from below the diaphragm to the aortic bifurcation with no obvious infiltration of the surrounding structures. (B) Sagittal view: The mass is also encasing superior mesenteric artery (long white arrow) and right renal artery (short white arrow). (C) Sagittal view displaying a large retroperitoneal mass compressing the inferior vena cava (arrow).

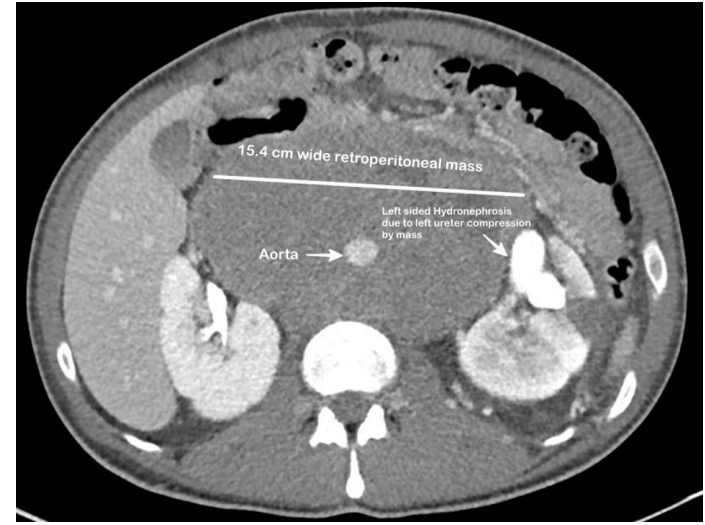

Figure 2 Axial view of the CT scan of the abdomen and pelvis. It demonstrates a large retroperitoneal mass which is encasing the abdominal aorta and leftsided hydronephrosis can also be seen due to ureteric compression by the mass.

tubules, due to the malignant transformation of primordial germ cells. ${ }^{2}$ Testicular tumours usually present as a painless swelling of the testis found by the patient, his partner or during physical examination. Patients with metastatic disease can present

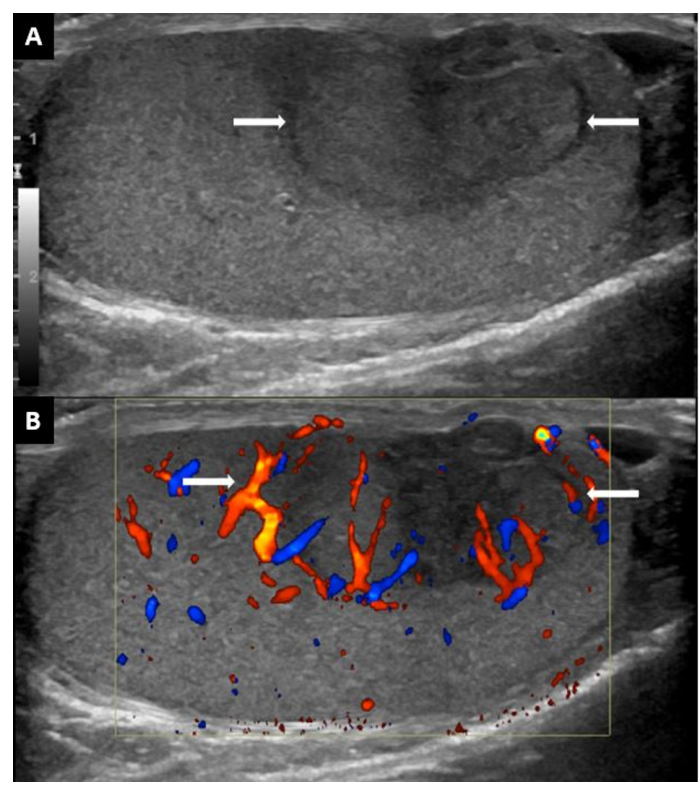

Figure 3 Doppler ultrasound of the testis. (A) A welldefined heterogeneously hypoechoic lesion showing the anterior mid-to-lower pole of the right testicle abutting the tunica albuginea. (B) The lesion is showing internal vascularity. No cystic components or calcifications within the lesion. 


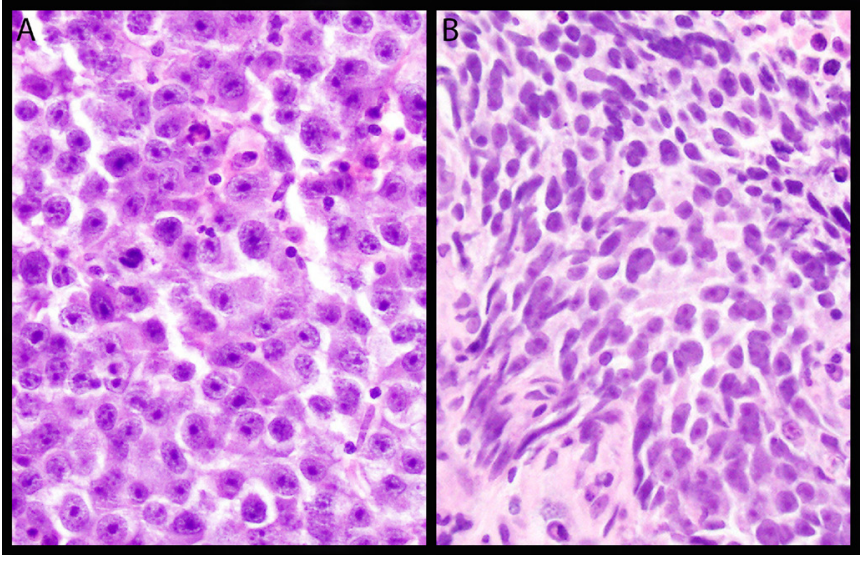

Figure 4 Histopathological features of the biopsied specimens. (A) H\&E-stained slide from the testicular specimen (200x magnification). (B) H\&E-stained slide from the retroperitoneal mass. Both images show epithelioid cells present in sheets with abundant clear to pink granular cytoplasm, polygonal nuclei and distinct nucleoli consistent with seminoma.

with local signs and symptoms (eg, abdominal discomfort, neck mass, the difficulty of breathing, bone pain, extremity swelling, etc) based on the location of the metastasis. Moreover, a giant retroperitoneal mass can have a mass effect on the surrounding vessels such as the aorta, its major branches and a mass effect on veins can lead to thrombosis such as inferior vena cava (IVC) thrombosis in our patient. ${ }^{23}$ Scrotal ultrasonography confirms the existence of mass and usually shows hypoechoic lesion without calcifications and cystic component in cases of seminoma.

In cases of seminoma, LDHlactate dehydrogenase) can be elevated and occasionally slightly elevated $\beta-H C G$ but seminomas never secrete $\mathrm{AFP}^{2}$ Radical orchiectomy is the standard of care for primary tumour and histopathology of the specimen confirms the diagnosis and differentiates the type of germ cell tumour. ${ }^{13}$ CT scan of the chest, abdomen and pelvis and MRI of the brain are used for staging. Patients must be provided with details about adolescent and young adults with cancer programmes and fertility preservation options. ${ }^{2}$
For patients with stage 1 seminoma, post orchiectomy options include active surveillance, retroperitoneal lymph node dissection or chemotherapy (one or two cycles). ${ }^{1}$ For most advanced tumours, chemotherapy remains the standard of care. ${ }^{12}$

\section{Learning points}

Seminoma is the most common subtype of testicular malignancy that usually presents as a painless scrotal swelling and metastatic disease can demonstrate focal manifestations.

- A huge abdominal mass can be misguiding and physicians might ignore examining the scrotum.

- Scrotal examination and ultrasonography can confirm the existence of a mass lesion that is usually solitary, hypoechoic without internal vascularity. Management can include orchiectomy, retroperitoneal lymph node dissection or chemotherapy, depending on the tumour stage.

Acknowledgements The authors are grateful to Dr Anthony N. Snow, MD (clinical associate professor of pathology at University of IOWA Health Care) for his valuable contribution in histopathological slides for this case.

Contributors AW, MHH and AY: Drafted and revised the manuscript. RT: Drafted and revised the manuscript and gave final approval for submission.

Funding The authors have not declared a specific grant for this research from any funding agency in the public, commercial or not-for-profit sectors.

Competing interests None declared.

Patient consent for publication Obtained.

Provenance and peer review Not commissioned; externally peer reviewed.

ORCID iD

Amman Yousaf http://orcid.org/0000-0003-0646-508X

\section{REFERENCES}

1 Nason GJ, Leao R, Hamilton RJ. Active surveillance in stage 1 disease: standard of care independent of risk factors? Curr Opin Urol 2020;30:245-50.

2 Rajpert-De Meyts E, McGlynn KA, Okamoto K, et al. Testicular germ cell tumours. Lancet 2016;387:1762-74

3 Boujelbene N, Cosinschi A, Boujelbene N, et al. Pure seminoma: a review and update. Radiat Oncol 2011;6:90.

Copyright 2021 BMJ Publishing Group. All rights reserved. For permission to reuse any of this content visit

https://www.bmj.com/company/products-services/rights-and-licensing/permissions/

BMJ Case Report Fellows may re-use this article for personal use and teaching without any further permission.

Become a Fellow of BMJ Case Reports today and you can:

- Submit as many cases as you like

- Enjoy fast sympathetic peer review and rapid publication of accepted articles

- Access all the published articles

Re-use any of the published material for personal use and teaching without further permission

Customer Service

If you have any further queries about your subscription, please contact our customer services team on +44 (0) 2071111105 or via email at support@bmj.com.

Visit casereports.bmj.com for more articles like this and to become a Fellow 